\title{
KERAJINAN SERAT DAUN PANDAN DITINJAU DARI PRINSIP KERAJINAN DI CHANTIKA HANDICRAFT
}

\author{
Maulida Habibah Tanjung ${ }^{*}$, Heri Soeprayogi ${ }^{2 *}$
}

\author{
Program Studi Pendidikan Seni Rupa Jurusan Seni Rupa Fakultas Bahasa dan Seni \\ Universitas Negeri Medan \\ Jl. Willem Iskandar Pasar V Medan Estate, Kec, Percut Sei Tuan, Kab. Deli Serdang, Kode Pos 20371 \\ Sumatera Utara. Indonesia \\ Email:maulidatanjung78@gmail.com,herisoeprayogi51@gmail.com
}

\begin{abstract}
Abstrak
Penelitian ini bertujuan untuk mengetahui desain dan mendeskripsikan prinsip-prinsip kerajinan yang terdapat pada karya kerajinan berbahan serat daun pandan di industri chantika handicraft Medan Sunggal. Metode penelitian yang digunakan adalah metode deskriptif kualitatif Teknik pengumpulan data yang digunakan adalah observasi, wawancara dan dokumentasi. Jumlah populasi penelitian 156 karya keseluruhan kerajinan berbahan serat daun pandan yang ada pada chantika handicraft Medan Sunggal. Teknik pengambilan sampel penelitian adalah purposive sampling, yaitu teknik pengambilan sampel sumber data deng an pertimbangaan tertentu, Dari 5 jenis produk berbahan serat daun pandan, diambil sebanyak 13 sampel karya yang terdiri dari 5 karya tas, 2 kary a dompet, 2 karya tempat tisu, 2 karya s andal, 2 kary a tempat aksesoris. Hasil penelitian ini menunjukkan bahwa desain bentuk kerajinan bahan serat daun pandan di industri ini bentuknya masih terkesan sederhana, bentuknya g eometris. Motif anyaman yang terdapat pada kerajinan bahan serat daun pandan ini antara lain motif anyaman lancar, sasag ganda dan kepang, serta motif pada kain batik terdapat ornamen khas sumatera utara. Sementara warna yang digunakan masih terkesan kurang variatif, sehingga tampilan tidak terlalu menarik. Untuk penerapan prinsip-prinsip kerajinan pada karya kerajinan berbahan serat daun pandan yang ada pada industri chantika handicraft Berdasarkan hasil nilai rata-rata oleh 3 tim penilai secara keseluruhan karya kerajinan berbahan serat daun pandan y ang ada di industri chantika handicraft Medan Sunggal sudah diterapkan dengan baik. Dilihat dari karya yang di kategori sangat baik di presentasi $25 \%$ sedangkan untuk kategoribaik di presentase $75 \%$. A spek penerapan prinsip kerajinan yang paling menonjol diantara prinsip lainnya yaitu pada prinsip irama. Prinsip ini mendapat rating penilaian paling baik dari tim penilai dan prinsip y ang paling lemah yaitu prinsip keseimbangan dimana pada prinsip ini mendapat rating penilaian terendah dari tim penilaian.
\end{abstract}

Kata Kunci: kerajinan, daun pandan, prinsip kerajinan.

\begin{abstract}
This study aims to determine the design and describe the principles of crafts contained in handicrafts made from pandanus leaffibers in the Medan Sunggal handicraft chantika industry. The research method used is descriptive qualitative method. Data collection techniques used are observation, interviews and documentation. The total population of the study was 156 works of handicrafts made from pandanus leaffiber in the Medan Sung gal handicraft chantika. The research sampling technique was purposive sampling, namely the sampling technique for data sources with certain considerations, of the 5 types of products made from pandan leaves, 13 samples were taken consisting of 5 bags, 2 purses, 2 tissue places sandals, 2 accessories holder work. The results of this study indicate that the design of the pandan leaffiber handicrafts in this industry still seems simple, geometric in shape. The woven motifs found in the pandan leaffiber craft include smooth woven motifs, double sasag and braids, as well as motifs on batik cloth which have a typical North Sumatra ornament. While the colors used still seem less varied, so the appearance is not too attractive. For the application of craft principles to handicrafts made from pandan leaves in the chantika handicraft industry. Judging from the works in the very good category, the presentation is $25 \%$ while for the good category the percentage is $75 \%$. The aspect of applying the principle of craft that stands out the mostamong other principlesis the principle of rhythm. This principle received the best rating rating from the assessment team and the weakest principle, namely the principle of balance, which in this principle received the lowest rating from the assessment team.
\end{abstract}

Keywords: craft, pandan leaves, the principle of craft. 


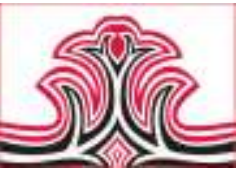

\section{PENDAHULUAN}

Kerajinan merupakan kegiatan kreatif yang berkaitan dengan kreasi, produksi dan distribusi produk yang dibuat oleh tenaga pengrajin dimulai dari des ain awal sampai proses penyelesaian produknya. Karya kerajinan meliputi barang yang terbuat dari serat alam, kulit, rotan, kayu, kaca, kain, marmer, tanah liat, kapur dan logam.

Serat daun pandan merupakan salah satu komoditi Hasil Hutan Bukan Kayu (HHBK) yang potensial dan bermanfaat sebagai bahan baku barang kerajinan. Pada awalnya daun pandan hanya dibuat barang kerajinan berupa tikar. Sesuai dengan permintaan pasar dan seiring dengan waktu,kerajinan pandan dibuat menjadi berbagai macam bentuk, seperti tas, sandal, kotak hantaran, boxfile, topi, dan lain sebagainya. Kerajinan anyaman yang menggunakan daun pandan sebagai baku bakunya sudah banyak ditemui, dan menjadi bahan yang selalu digunakan.

Kota Medan khususny a di Sunggal terdapat salah satu industri yang menghasilkan produk kerajinan dari bahan serat alam, di industri ini memproduksi bahan serat alam menjadi karya seni seperti tas, tempat tisu, dompet, sandal, dan lain sebagainya. Salah satu kerajinan bahan serat alam yang banyak diperoleh di industri ini adalah serat daun pandan. Chantika Handicraft merupakan salah satu industri kerajinan yang memproduksi barang-barang kerajinan yang memanfaatkan serat alam sebagai bahan utama nya, Indus tri iniberada di Jalan Binjai km 10 Gg Damai No. 19 Medan Sunggal. Produk yang dihasilkan oleh Chantika Handicraft sebagian besar adalah benda pakai. Produk yang dihasilkan dalam setiap bulannya kurang lebih 150 buah. Namun jumlah produksi tersebut tidak tetap, bahkan dapat melebihi atau dapat juga kurang darijumlah tersebut. (Wawancara Annisa, Pada 03 Mei 2020, 14.00 WIB).

Dari berbagai karya produk kerajinan yang ada di industri ini, terdapat beberapa prinsip kerajinan yang digunakan oleh peneliti untuk menjadi indikator dalam penilaian karya kerajinan berbahan serat daun pandan. Prinsip kerajinan yang terdapat dalam karya kerajinan ini dan digunakan dalam penerapan karya ini diantara nya adalah: prinsip proporsi, prinsip kesimbangan, prinsip irama dan prinsip dominasi (pusat perhatian). Dalam pembuatan hasil produk karya kerajinan nya dari hasil observasi dan wawancara sebelumny adengan pemilik industri, pemilik menyatakan adany a kesulitan mendesain produk yang sesuai dengan permintaan konsumen dan banyaknya pesanan konsumen yang menginginkan warna atau desain yang menarik. Sebab
Gorga : Jurnal Seni Rupa

Volume 09 Nomor 02 Juli-Desember 2020

p-ISSN: 2301-5942 | e-ISSN: 2580-2380

itu produk yang dihasilkan desain nyacenderung masih mengikuti desain-desain yang dipasarkan pada umumnya dan dalam pembuatan kerajinan nya masih terdapat beberapa kelemahan yang berkaitan dengan prinsip-prinsip kerajinan.

\section{KAJIAN TEORI \\ 1. Pengertian Kerajinan}

Menurut Hasan Alwi (2001:992) dijelaskan bahwa kerajin an berasal darikata rajin mendapat awalan kedan akhiran -an, dimana kerajinan disini bersifat melatih diri ke arah rajin (gerakan aktif). Gerakan aktif tersebut sudah bis a dikerjakan sejak kecil baik sengaja maupun tidak sengaja. Sebagai contoh; anyaman, potong-potongan pakaian, melipat-lipat kertas, mengukir kayu, batu, logam, gading, batik, dan sebagainya.

Menurut Raharjo (2011:16) mengatakan bahwa: kerajinan adalah suatu hal yang bernilai sebagai kreativitas alternatif, suatu barang yang dihasilkan melalui keterampilan tangan. Umumnya barang kerajinan banyak dikaitkan dengan unsur seni yang kemudian disebut seni kerajinan. Seni kerajinan adalah implementasi dari karya seni kriya yang telah diproduksi secara massal (mass product).

Oho Garha (1990: 3) menyatakan bahwa "Kerajinan merupakan pengalihan bahasa dari "handicraft" dalam bahasa Inggris, y ang bermakna sebagaikegiatan yang dilakukan secara manual dan artis tik oleh pelakunya yang disebut perajin. Pengertian ini sengaja dipilih untuk tidak melibatkan jenis kerajinan lain yang dalam pembuatannya tidak menuntut penampilan yang artistik.

Berdasarkan beberapa pendapat di atas maka dapat disimpulkan bahwa kerajinan merupakan karya seni rupa tiga dimensi yang dibuat oleh tangan terampil perajin, yang mengandung nilai estetis, nilai fungsional, dan nilai ekonomis .

\section{Pengertian Pewarnaan Alami}

Menurut Noerati (2013: 1) menyatakan bahwa "Serat adalah suatu jenis bahan berupa potongan-potongan komponen yang membentuk jaringan memanjang yang utuh". Manusia menggunakan serat dalam banyak hal yaitu untuk membuat tali, kain, benang atau kertas. Berdasarkan sumbernya serat dapat digolongkan menjadi dua jenis yaitu serat alam dan serat sintetis.

Menurut Tjitrosoepomo (2007: 3) menyatakan bahwa "Serat pandan termasuk golongan jenis serat alami (natural fiber) yang berasal dari suku pandanaceae 
yang tumbuh di pesis ir pantai". Tanaman pandan terdiri dari batang, daun, bunga, buah, biji, dan akar, yang merupakan salah satu jenis tanaman semak, perdu atau pohon dengan batang berupa liana dengan batangbatang memanjat yang mempunyai tinggi sekitar $11 \mathrm{~m}$. Jenis tanaman pandan y ang digunakan dalamkerajinan adalah tanaman pandan duriatau pandanus tectorius.

Menurut Widjaja (1989: 2), Serat Pandan merupakan segolongan tumbuhan monokotil dari genus Pandanus dalam anggota Pandanaceae. Sebagian besar anggotanya tumbuh tersebar di daerah tropika, di tepitepi pantai dan sungai-sungai. Ukuran tinggi batang mencapai 4-14 $\mathrm{m}$ dan bias anya tu mbuh padaketinggian 20-600 mdpl dan menghasilkan daun 10-300 lembar per batang per tahun.

Berdasarkan pendapat di atas, Disimpulkan bahwa serat daun pandan merupakan termasuk jenis golongan serat alami dan segolongan tumbuhan monokotil, pandan dapat digunakan untuk berbagai kebutuhan, salah satu nya pandan dapat digunakan sebagai bahan untuk kerajinan.

\section{Pengertian Daun Jambu Biji}

Menurut Aryo Sunaryo (2002:31), Prinsip-prinsip terdapat pada kerajinan yaitu:

(1)Prinsip kesatuan, merupakan prinsip pengorganisasian unsur-unsur rupa yang paling mendas ar. Tujuan akhir dari penerapan prinsip-prinsip desain yang lain, seperti keseimbangan, kesebandingan, irama, dan lainnya adalah untuk mewujudkan kesatuan yang padu atau keseutuhan. (2)Prinsip keserasian, merupakan prinsip desain yang mempertimbangkan keselarasan dan keserasian antar bagian dalam suatu keseluruhan sehingga cocok satu dengan yang lain, serta terdapat keterpaduan yang tidak saling bertentangan. Susunan yang harmonis menunjukkan adanya keserasian dalam bentuk, raut, garis, ukuran, warna, dan tekstur. (3)Prinsip irama,merupakan suatu gerakan peralihan yang berkesinambungan teratur dan serasi. (4)Prinsip dominasi,merupakan pengaturan peran atau penonjolan atas bagian innya dalam suatu keseluruhan yang menjadikan pusat perhatian (center of interest) dan merupakan tekanan (emphasis) yang menjadi bagian penting dan diutamakan. (5)Prinsip keseimbangan, merupakan cara pengaturan berat ring annya serta letak kedudukan bagian-bagian dapat dibedakan menjadi: (a) keseimbangan setangkup (simetri) bila belahan kiri dan kanan memiliki kesamaan wujud, ukuran, dan jarak penempatan, (b) keseimbangan senjang (asimetri) memiliki bagian yang tidak sama antara belahan kiri dan kanan, tetapi dalam keadaan yang tidak berat
Gorga : Jurnal Seni Rupa

Volume 09 Nomor 02 Juli-Desember 2020

p-ISSN: $2301-5942$ | e-ISSN: 2580-2380

sebelah, dan (c) keseimbangan memancar (radial) merupakan bentuk keseimbangan yang diperoleh melalui penempatan bagian-bagian susunan di seputar pusat sumbu gaya berat. (6) Prinsip kesebandingan, berarti hubungan antara bagian atau antara bagian terhadap keseluruhannya yang bertalian dengan ukuran, luas sempitnya bagian, panjang pendeknya bagian, atau tinggi rendahnya bagian yang bertujuan agar mencapai kesesuaian dan kes eimbangan sehingga diperoleh kesatuan yang memuaskan.

Menurut Stewart (2011 : 234) menjelaskan bahwa keseimbangan mengacu pada distribusi berat atau kekuatan di antara unit-unit visual. Seperti keseimbangan fisik, keseimbangan visual membutuhkan keseimbangan dalam ukuran, berat visual, dan gaya. Keseimbangan visual dapat diciptakan melalui ketiadaan serta kehadiran bentuk.

Irama dalam karya seni rupa menjadikan suatu karya menjadi hidup, tidak membosankan. Menjadikan karya seolah punya kekuatan dan tidak monoton, tidak membosankan. Sehingga karya punya kekuatan dan dinamika psikologi. Pengertian irama dalamseni rupa adalah gerak perulangan secara teratur dan terus menerus (Zulkifli, 2018:50).

Dari uraian dapat disimpulkan bahwa Prinsip-prinsip merupakan bagian yang penting dalam pembuatan karya kerajinan, untuk mencapai hasil atau tujuan yang diharapkan.

Pada karya kerajinan berbahan serat daun pandan adapun prinsip kerajinan yang digunakan oleh peneliti untuk menjadi indikator dalam penilaian karya kerajinan berbahan serat daun pandan diantara nya terdiri dari 4 diantaranya: prinsip proporsi, keseimbangan, irama dan dominasi (pusat perhatian).

\section{METODE PENELITIAN}

Dalam suatu penelitian, metode memegang peranan yang sangat penting. Hal inidis ebabkan karena semua kegiatan yang dilakukan dalam penelitian sangat bergantung kepada metode yang digunakan .

"Metode kualitatif menekankan pada makna, faktafakta, penalaraan, defenisi suatu situasi tertentu. Metode penelitian kualitatif dalah metode penelitian yang berlandaskan pada filsafat post positivisme, digunakan untuk meneliti pada kondisi objek yang alami” (Sugiyono 2017: 14).

Adapun metode yang digunakan dalam penelitian ini adalah metode deskriptif kualitatif, metode deskriptif 


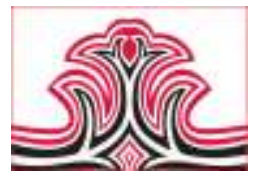

kualitatif yaitu dengan menguraikan masing-masing subjek yang akan diteliti dan disesuaikan dengan kerangka teori yang telah ditetapkan dan teknik pengumpulan data yang digunakan adalah observasi (observation), wawancara (interview) dan dokumentasi. Sesuai dengan masalah yang diteliti, maka penelitian ini di laksanakan di Jl. Binjai km 10, lorong 7 Gg.Damai No. 19, Paya Geli, Kec. Medan Sunggal, Sumatera Utara.

\section{HASIL DAN PEMBAHASAN}

\section{Hasil}

Hasil penelitian ini mengacu kepadarumus an mas alah, yaitu tentang desain dan penerapan prinsip-prinsip kerajinan pada karya kerajinan berbahan serat daun pandan pada industri chantika handicraft Medan Sunggal yang dalampenilaian karya berpedoman pada 4 as pek penilaian yaitu proporsi, kes eimbangan, irama dan dominasi. Data hasil penelitian menunjukkan bahwa data yang ditemukan di lapangan pada penelitian ini ada 5 jenis produk karya kerajinan berbahan serat daun pandan, adapun jenis produk karya kerajinan berbahan serat daun pandan di industri chantika handicraft yang dijadikan sampel yaitu: Tas, Dompet, Tempat Tisu, Sandal, dan Tempat Aksesoris. Berikut ini 13 karya kerajinan yang terdapat di chantika handicraft:

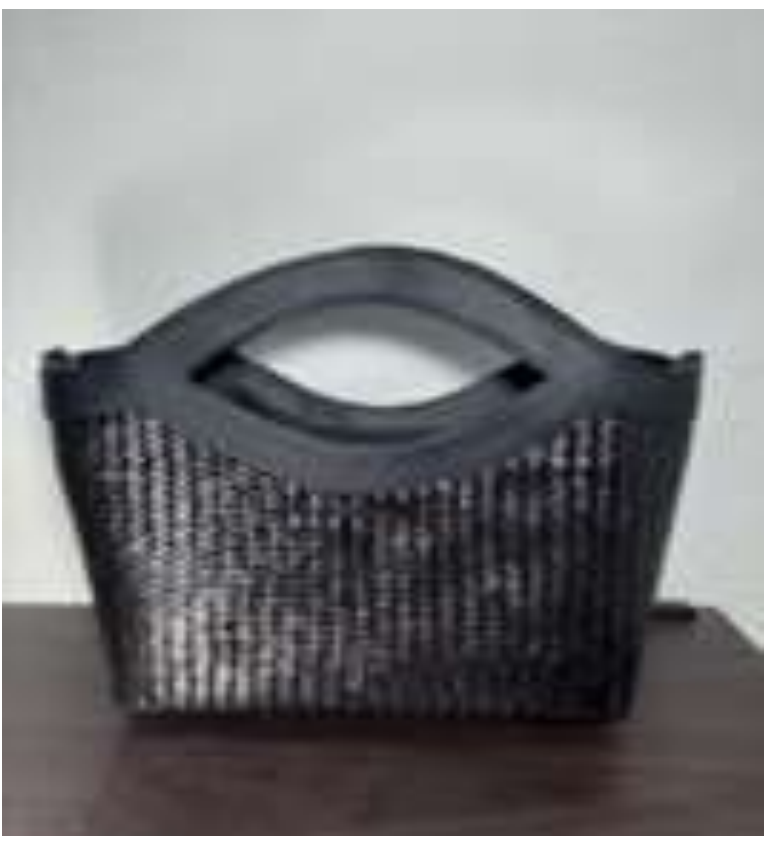

Gambar 1. Tas Tangan Anyam Hitam (Tanjung, 2020)
Gorga : Jurnal Seni Rupa

Volume 09 Nomor 02 Juli-Desember 2020 p-ISSN: 2301-5942 | e-ISSN: 2580-2380

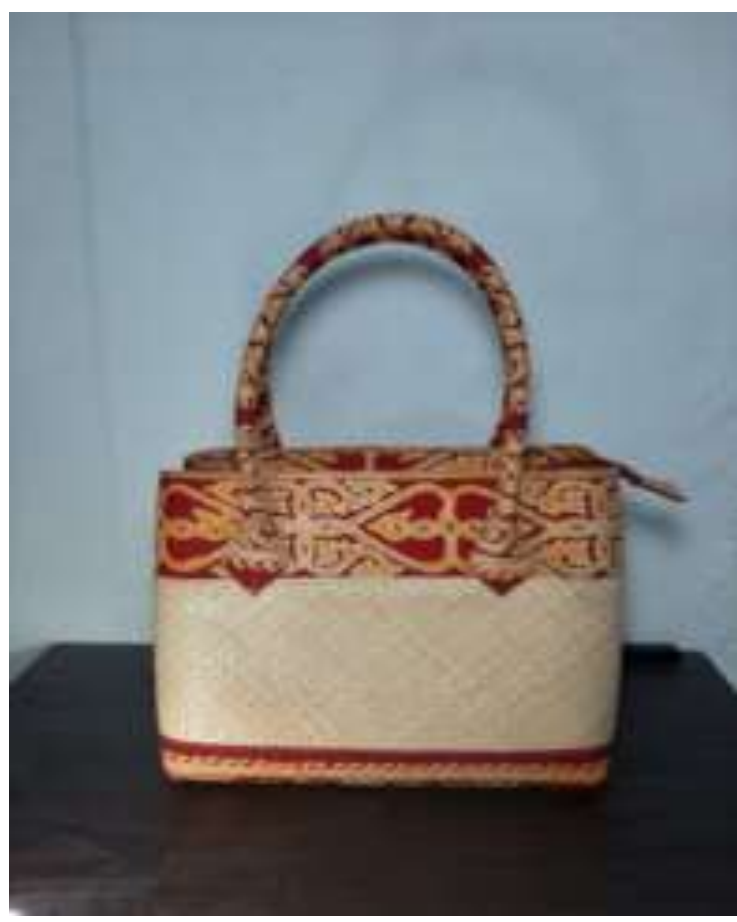

Gambar 2. Tas Tangan Kombinasi Motif Batik (Tanjung, 2020)

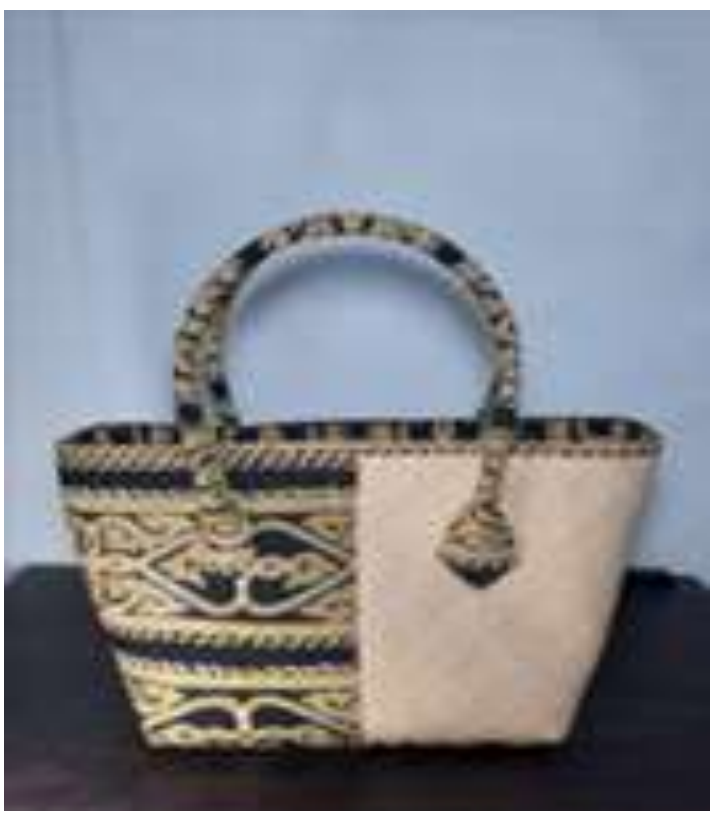

Gambar 3. Tas Tangan Setengah Batik pada Badan Tas (Tanjung, 2020) 

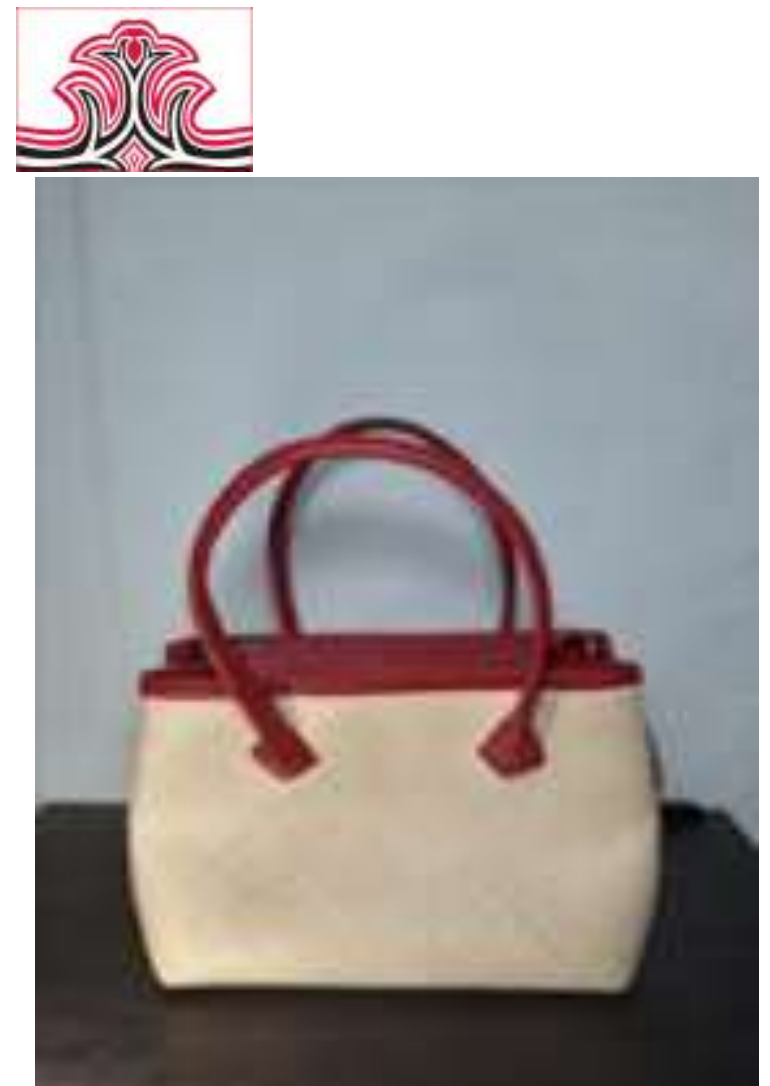

Gambar 4. Tas Tangan Polos dengan Anyaman Warna Original (Tanjung, 2020)

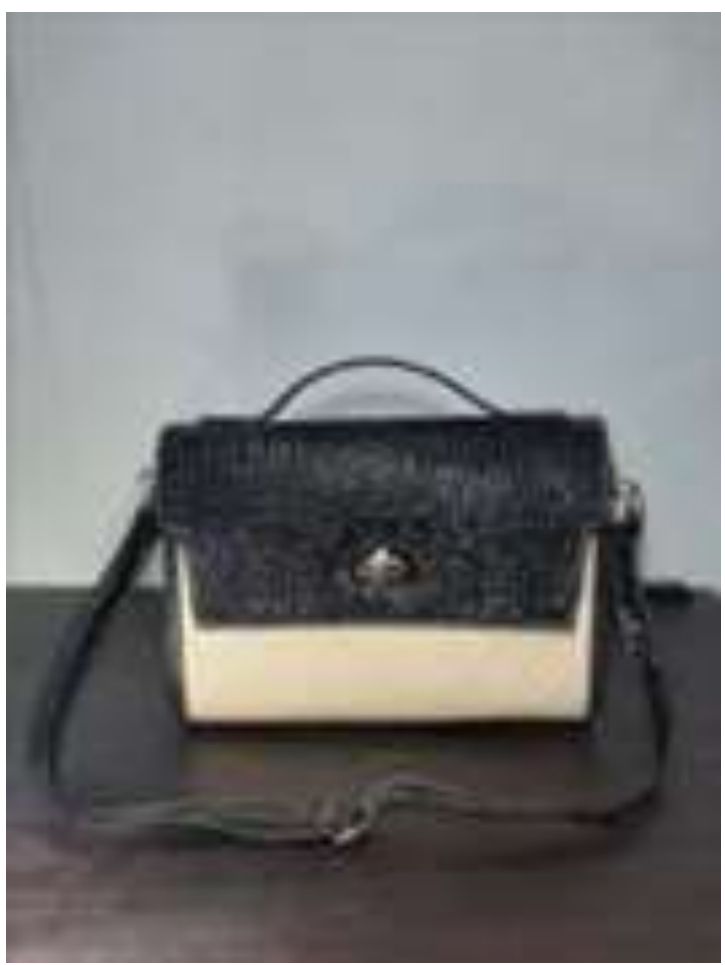

Gambar 5. Tas Pinggang Kombinasi dengan Warna Hitam (Tanjung, 2020)
Gorga : Jurnal Seni Rupa

Volume 09 Nomor 02 Juli-Desember 2020

p-ISSN: 2301-5942 |e-ISSN: 2580-2380

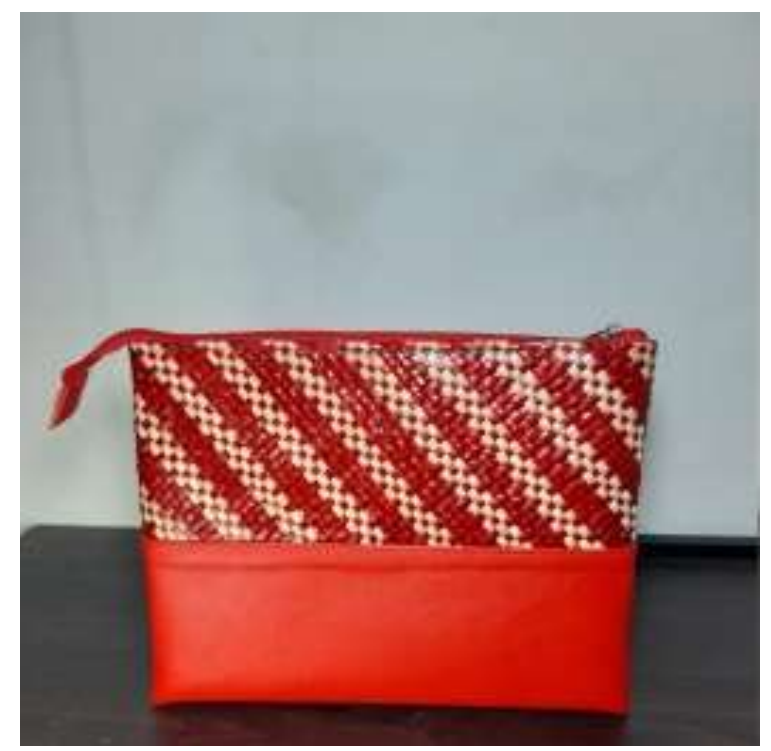

Gambar 6. Dompet Tangan Kombinasi Warna Merah dengan Warna Original (Tanjung, 2020)

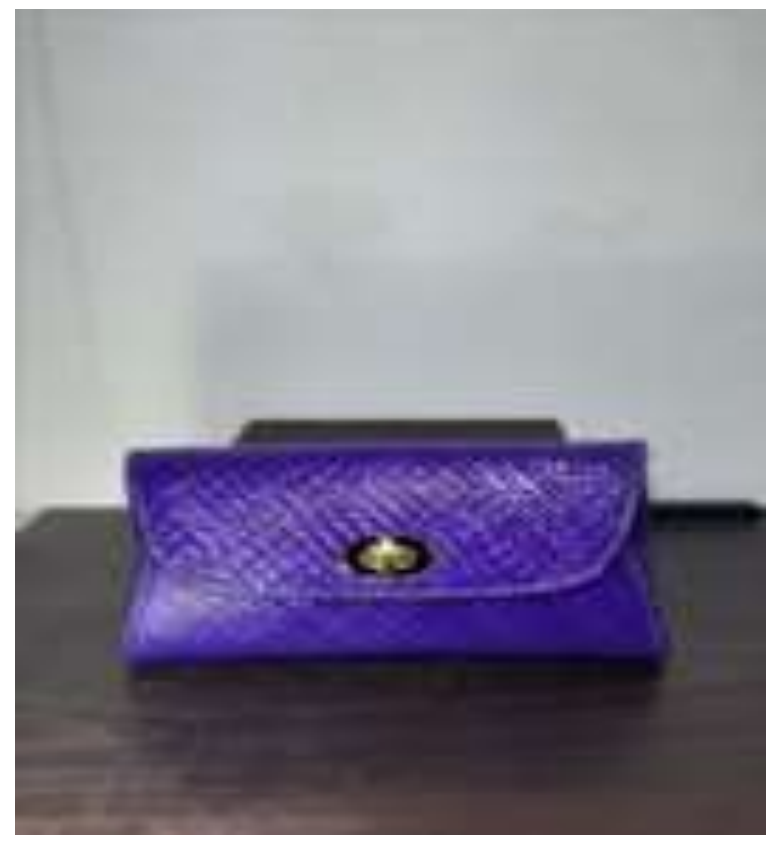

Gambar 7. Dompet Tangan Warna Ungu Terang (Tanjung, 2020) 

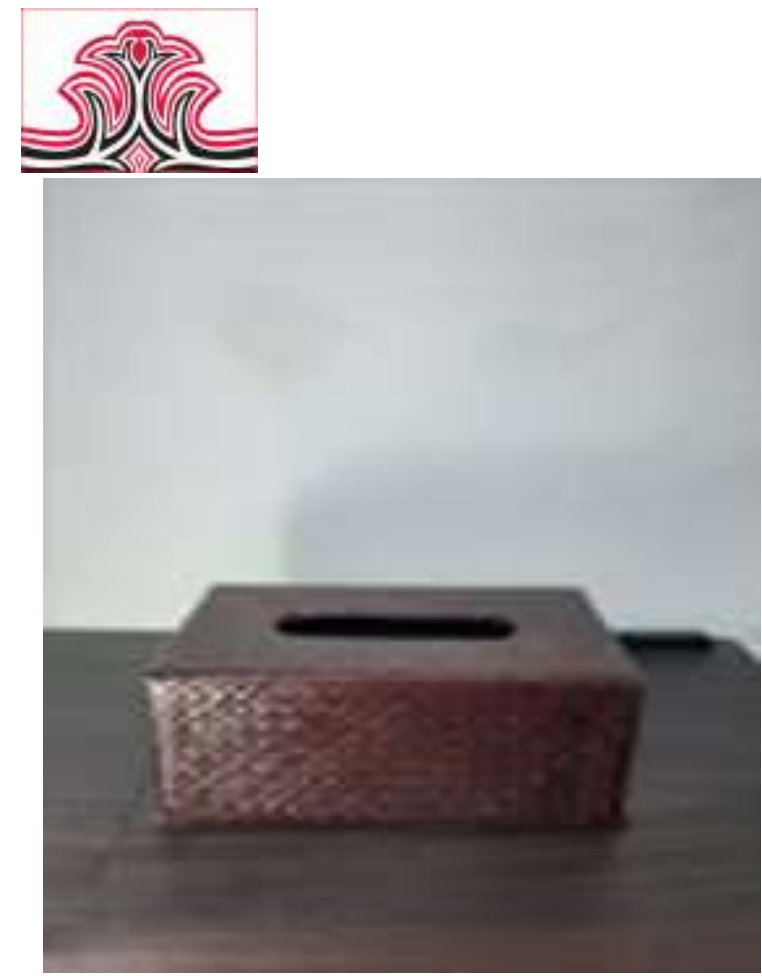

Gambar 8. Tempat Tisu Kombinasi Warna Cokelat (Tanjung, 2020)

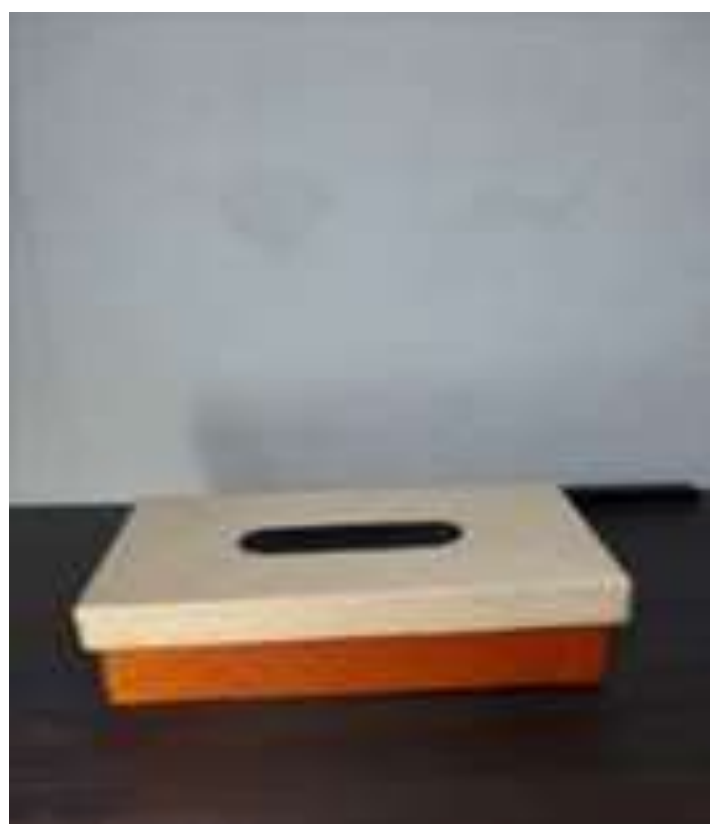

Gambar 9. Tempat Tisu Kombinasi Warna Orange dan Warna Original

(Tanjung, 2020)
Gorga : Jurnal Seni Rupa

Volume 09 Nomor 02 Juli-Desember 2020

p-ISSN: $2301-5942$ | e-ISSN: 2580-2380

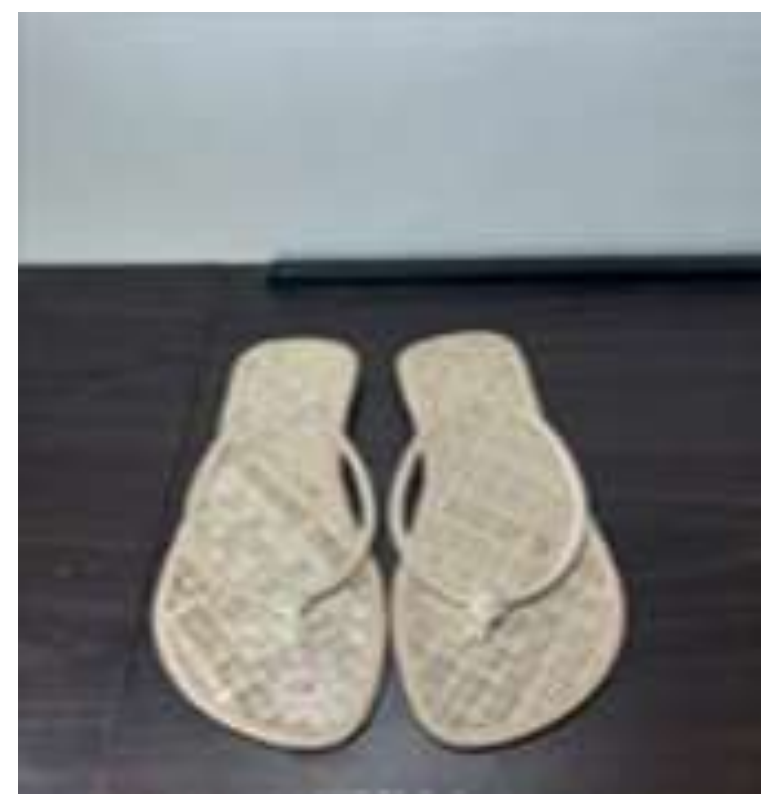

Gambar 10. Sendal Jepit Polos

(Tanjung, 2020)

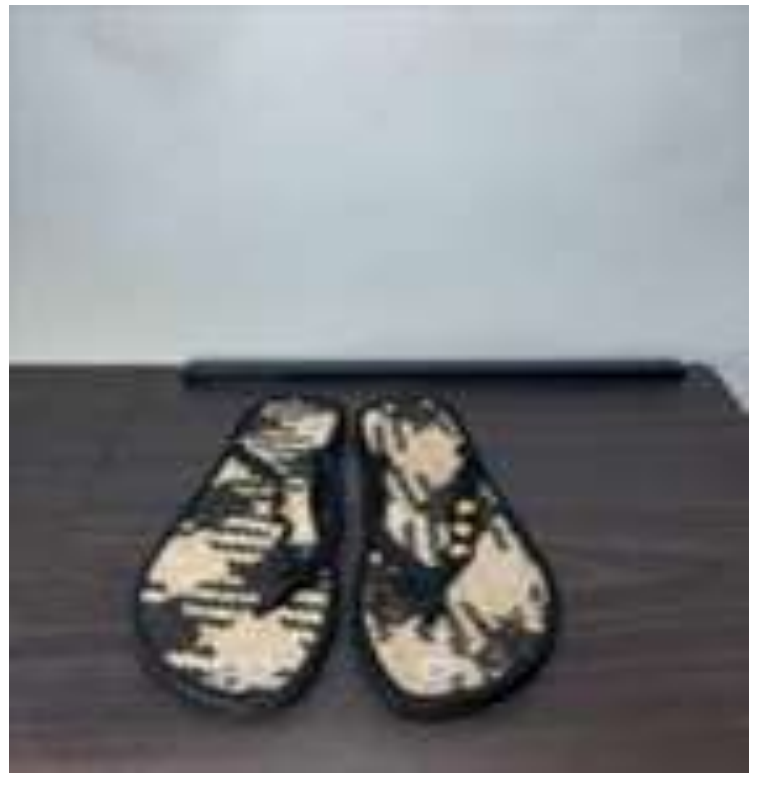

Gambar 11. Sendal Jepit Bermotif (Tanjung, 2020) 


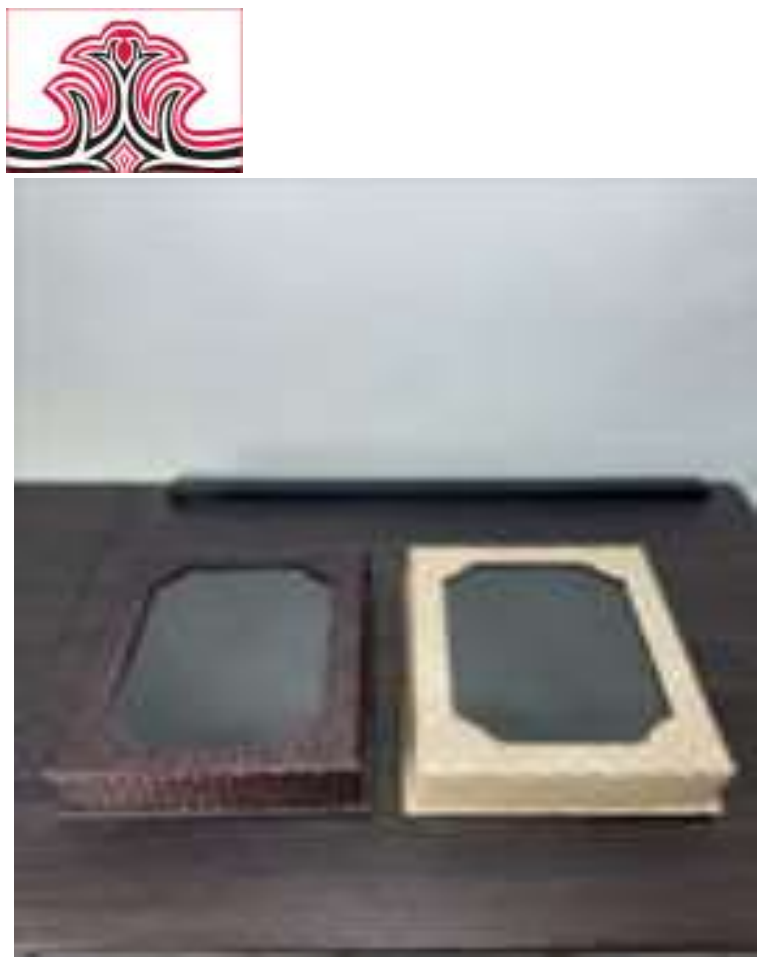

Gambar 12. Tempat Perhiasan (Tanjung, 2020)

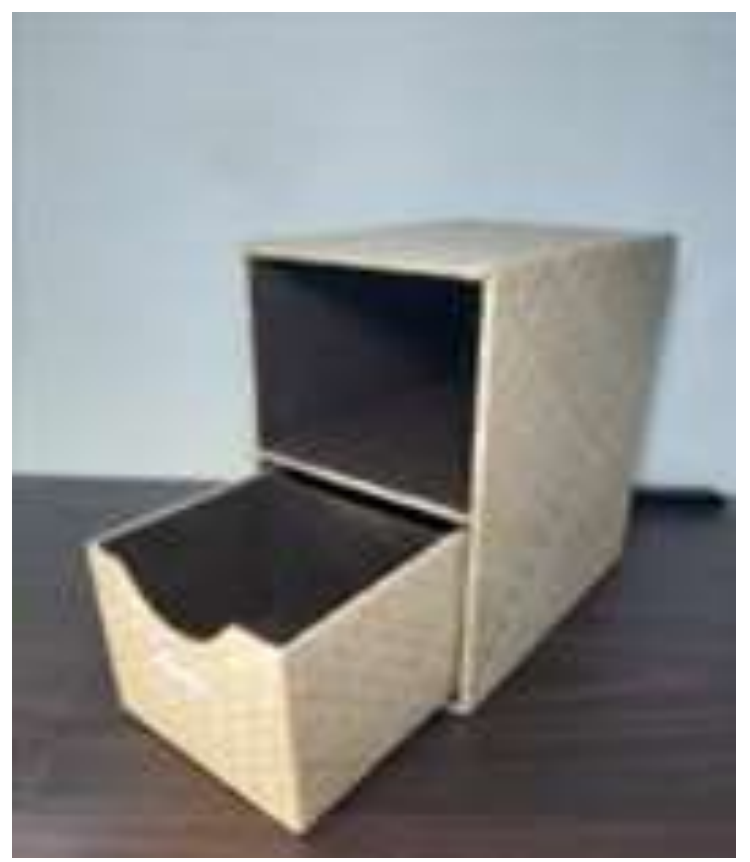

Gambar 13. Tempat Perhiasan Dua Tingkat (Tanjung, 2020)

\section{Pembahas an}

Berikut ini adalah 13 deskripsi karya kerajinan berbahan serat daun pandan yang terdapat pada industri kerajinan chantika handicraft Medan Sunggal dilihat berdas arkan pedoman prinsip-prinsip kerajinan yang terdapat pada kerajinan serat daun pandan, yang terdiri dari: prinsip proporsi, keseimbangan, irama dan dominasi.
Gorga : Jurnal Seni Rupa

Volume 09 Nomor 02 Juli-Desember 2020

p-ISSN: 2301-5942 | e-ISSN: 2580-2380

Pada hasil gambar 1 diperoleh bahwa prinsip proporsi pada karya 1 kerajinan berbahan serat daun pandan ini secara keseluruhan sangat baik, terlihat pada bidang bentuk utama dengan bidang sisi pendukung selaras, pada prinsip keseimbangan secara keseluruhan juga sangat baik, terlihat pada penempatan serat daun pandan dengan elemen pendukung seperti bahan kulit seimbang, untuk prinsip irama pada karya secara keseluruhan sangat baik, terlihat pada pola anyaman yang disusun sejajar dan dilakukan secara berulang-ulang sehingga menimbulkan kesan gerak, dan untuk prinsip dominasi pada karya ini secara keseluruhan sangat baik, terlihat adany a keunikan tekstur dari serat daun pandan yang dianyam menjadi sebuah pola. Hanya saja pada warna tidak banyak warna yang ditonjolkan karena hanya menggunakan warna hitam.

Pada hasil gambar 2 diperoleh bahwa prinsip proporsi pada karya 2 kerajinan berbahan serat daun pandan ini secara keseluruhan baik, hanya saja terlihat kurang harmonis pada bentuk elemen utama dengan elemen pendukung berbahan kain, pada prinsip keseimbangan pada karya secara keseluruhan juga baik, hanya saja kurang seimbang karena menitik beratkan keseimbangan nya pada bagian atas saja, pada prinsip irama yang ada pada karya secara keseluruhan juga dinilai sangat baik, karena terdapat elemen pendukung yang disusun secara berulang sehingga menimbulkan kesan gerak pada objek, dan penataan iramanya teratur terlihat dari susunan any aman, dan untuk prinsip dominasi pada kary a ini secara keseluruhan sangat baik, karena terdapat elemen yang mendominasi yaitu bahan kain batik.

Pada hasil gambar 3 diperoleh bahwa proporsi pada karya 3 kerajinan berbahan serat daun pandan ini secara keseluruhan s angat baik, karenabentuk elemen utama dan pendukung tersusun dengan ukuran yang sama sehingga terlihat seimbang, prinsip keseimbangan pada karya kerajinan ini secara keseluruhan baik, terlihat pada elemen utama dan pendukung membagi bidang pada tiap sisi dan kerajinan, prinsip irama pada karya ini secara keseluruhan juga sangat baik, karena terdapat elemen pendukung yang disusun secara berulang, sehingga menimbulkan kesan gerak, prinsip dominasi pada karya ini secara kes eluruhan baik, terlihat dari adanya bagian yang ditonjolkan disini yaitu bagian motif desain dan perpaduan warna pada kain batik.

Pada hasil gambar 4 diperoleh bahwa prinsip proporsi pada karya 4 kerajinan berbahan serat daun pandan ini secara keseluruhan baik, terlihat pada 
elemen utama serat daun pandan dan elemen pendukung yang tersusun secara harmonis, prinsip keseimbangan pada karya ini secara keseluruhan juga sangat baik, terlihat elemen pendukung tidak berat sebelah dengan keseluruhan bidang, prinsip irama pada karya ini secara keseluruhan juga baik, terlihat pada penataan pola anyaman terlihat teratur baik bentuk dan arahnya mengikuti bidang kerajinan, dan untuk prinsip dominasi pada karya ini secara keseluruhan baik, terlihat pada elemen pendukung yang tampak menonjol karena pemberian warna merah yang cukup mencolok, sehingga menjadikan karya tersebut lebih menarik.

Pada hasil gambar 5 diperoleh bahwa proporsi pada karya 5 kerajinan berbahan serat daun pandan ini secara keseluruhan sangat baik, terlihat pada ukuran yang seimbang antara elemen utama dengan elemen pendukung, pada prinsip keseimbangan untuk karya kerajinan ini secara kes eluruhan sangat baik, terlihat dari penempatan warna hitam pada kulit dengan keseluruhan objek stabil dengan bidang utama, pada prinsip irama pada karya kerajinan ini secara keseluruhan jug a terlihat sangat baik, karena terdapat susunan yang berulang pada beberapa elemen pendukung sehingga menimbulkan kesan gerak, dan untuk prinsip dominasi pada karya ini secara keseluruhan juga sangat baik, karena terdapat penonjolan terhadap motif pada 2 elemen yaitu elemen utama dan pendukung.

Pada hasil gambar 6 diperoleh bahwa prinsip proporsi pada kary a 6 kerajinan berbahan serat daun pandan ini secara keseluruhan sangat baik, terlihat dari bentuk elemen pendukung bahan kulit tersusun secara harmonis bersama elemen utama yaitu serat daun pandan, prinsip keseimbangan pada karya kerajinan ini secara keseluruhan juga sangat baik, terlihat pada penempatan warna pada elemen utama tersusun miring sejajar mengikuti bentuk kerajinan sehingga menimbulkan kesan harmonis, prinsip irama pada karya ini secara keseluruhan terlihat s angat baik, terlihat dari beberapa elemen utama serat daun pandan y ang dis usun secara berulang baik pada pola maupun warna sehingga menimbulkan kesan gerak pada objek kerajinan ini, dan untuk prinsip dominasi pada karya ini secara keseluruhan baik, terlihat dari adanya penonjolan motif yang dimunculkan pada karya kerajinan serat daun pandan ini, dilihat dari pola anyaman yang disusun sejajar mengikuti bidang serta penonjolan warna.

Pada hasil gambar 7 diperoleh bahwa prinsip proporsi pada karya 7 kerajinan berbahan serat daun pandan ini secara keseluruhan sangat baik, terlihat
Gorga : Jurnal Seni Rupa

Volume 09 Nomor 02 Juli-Desember 2020

p-ISSN: 2301-5942 | e-ISSN: 2580-2380

dari bentuk elemen yang ters usun harmonis, prinsip keseimbangan pada karya kerajinan ini secara keseluruhan juga terlihat sangat baik, terlihat dari adany a keseimbang an ukuran serta bentuk an tara sisi kanan dan kiri bidang, pada prinsip irama untuk karya kerajinan berbahan serat daun pandan ini secara keseluruhan sangat baik, karena terdapat beberapa elemen yang disusun secara berulang, dan untuk prinsip dominasi pada karya kerajinan ini secara keseluruhan dikatakan sangat baik, karena adanya penonjolan pada warna unggu dan aksen jepitan.

Pada hasil gambar 8 diperoleh bahwa prinsip proporsi pada karya 8 kerajinan berbahan serat daun pandan ini secara keseluruhan baik, terlihat pada ukuran yang seimbang antara bentuk dengan motif, prinsip keseimbangan juga baik, terlihat dari bes arnya bentuk kary a serat daun pandan dan elemen pendukung seimbang karena bentuk elemen pada bahan kertas karton mengikuti bentuk bidang kerajinan dan menjadi kerangka dalam kerajinan ini, untuk prinsip irama pada karya kerajinan ini secara keseluruhan baik, terlihat adanya pengulangan pada elemen serat daun pandan dan prinsip dominasi pada karya kerajinan ini secara keseluruhan baik, terlihat adanya penonjolan warna yang ditonjolkan pada karya ini yaitu warna cokelat tua yang memenuhi seluruh permukaan kerajinan.

Pada hasil gambar 9 diperoleh bahwa prinsip proporsi pada karya 9 kerajinan berbahan serat daun pandan ini secara keseluruhan baik, terlihat dari terdapatnya proporsi ukuran yang seimbang antara bentukdan warnapadaobjek, prinsip keseimbangan pada kary a kerajinan ini secara kes eluruhan juga baik, terlihat dari besarnya bentuk karya dengan elemen tambahan seimbang, karena bentuk elemen tambahan mengikuti bentuk bidang kerajinan, untuk prinsip irama pada karya kerajinan berbahan serat daun pandan inijuga baik, terlihat dari elemen utama serat daun pandan pada polanya tersusun secara harmonis dengan bentuk dan ukuran yang terdapat juga pengulangan keberkalaan bentuk dan jarak dalam penyusunan karya ini sehingga memunculkan kesan irama dan prinsip dominasi pada karya kerajinan ini secara keseluruhan dikatakan baik, karena adanya kontras warna yang menonjol pada bagian wadah tempat tisu pada karya ini

Pada hasil gambar 10 diperoleh bahwa prinsip proporsi pada karya 10 kerajinan berbahan seratdaun pandan ini keseluruhan baik, dilihat dari bagian sisi alas dengan karet sol dibawahnya pada karya ini memiliki bentuk yang sama sehingga terlihat 
proporsional, prinsip keseimbangan pada karya kerajinan ini secara keseluruhan juga baik, karena antara alas kiri dan kanan sandal dilihat dari arah pandang dari segala sis inya terlihat seimbang, untuk prinsip irama pada karya kerajinan ini juga baik, terlihat dari adanya pengulangan bentuk yang terjadi pada motif pola anyaman yang sejajar mengikuti bentuk alas, dan pada prinsip dominasi pada karya kerajinan ini secara kes eluruhan baik, dilihat adanya tekstur alami yang menonjol pada karya ini.

Pada hasil gambar 11 diperoleh bahwa prinsip proporsi pada karya 11 kerajinan berbahan seratdaun pandan inis ecara keseluruhan baik, karena bagian sisi alas dengan karet sol dibawahnya pada karya kerajinan ini memiliki bentuk yang sama dan seimbang, sehingga terlihat proporsional, prinsip keseimbangan pada karya ini secara keselunhan baik, karena antara alas kiri dan kanan sandal dilihat dari arah pandang dari segala sisi nya terlihat seimbang, untuk prinsip irama pada kary a kerajinan ini keseluruhan juga baik, terlihat dari adanya keberkalaan bentuk yang dimunculkan dan terdapat perulangan jarak pada bentuk dan keberkalaan arah yang dis usun secara berulang sehingga menimbulkan kesan gerak, dan prinsip dominasi pada karya kerajinan ini secara kes eluruhan baik, karena terdapat bentuk motif anyam dan corak warna yang variatif yang tersusun secara diagonal pada bagian alas karya.

Pada hasil gambar 12 diperoleh bahwa prinsip proporsi pada karya 12 kerajinan berbahan seratdaun pandan ini secara keseluruhan baik, terlihat dari bagian satu sisi desain dengan lainnya pada karya kerajinan ini memiliki bentuk yang sama dan seimbang, prinsip keseimbangan pada karya kerajinan ini secara keseluruhan juga baik, terlihat dari terdapatnya bentuk motif pola anyaman yang tersusun sejajar men gikuti seluruh permukaan bidang, dengan ukuran dan bentuk pola yang sama sehingga menimbulkan kesan harmonis, untuk prinsip irama pada karya kerajinan ini secara keseluruhan baik, terlihat dari adanya pengulangan elemen yang terdapat pada elemen serat daun pandan dengan ukuran dan bentuk yang sama, dan prinsip dominasi pada karya kerajinan ini secara keseluruhan terlihat baik, karena adanya bentuk dan kontras warna yang menonjol pada karya ini.

Pada hasil gambar 13 diperoleh bahwa prinsip proporsi pada karya 13 kerajinan berbahan seratdaun pandan ini secara keseluruhan baik, terlihat dari bagian sisi atas desain deng an sisi bawah pada karya kerajinan ini memilik bentuk yang sama dan seimbang, sehingga terlihat proporsional, prinsip
Gorga : Jurnal Seni Rupa

Volume 09 Nomor 02 Juli-Desember 2020

p-ISSN: 2301-5942 | e-ISSN: 2580-2380

keseimbangan pada karya kerajinan ini secara keseluruhan juga baik, terlihat dari penempatan elemen utama dan pendukung tidak berat sebelah, saling berdampingan menjadi satu kesatuan, dan prinsip irama pada karya kerajinan ini secara keseluruhan terlihat baik, karena memiliki bentuk elemen yang disusun secara berulang-ulang dengan ukuran yang sama dan dikomposisikan dengan baik sehingga karya ini terlihat selaras, dan prinsip untuk dominasi pada karya kerajinan berbahan serat daun pandan ini secara keseluruhan baik, terlihat dani adanya penonjolan bentuk dan motif pola anyaman pada karya ini, walaupun masih terlihat sederhana. Hanya saja penonjolan warna tidak terlihat pada karya ini.

\section{KESIMPULAN DAN SARAN}

\section{Kesimpulan}

Berd Karya kerajinan berbahan serat daun pandan secara kes eluruhan sudah menerapkan prinsip-prinsip kerajinan dengan baik, dilihat dari prinsip proporsi dan beberapa karya kerajinan berbahan serat daun pandan pada industri kerajinan chantika handicraft Medan Sunggal terlihat baik dari kes elarasan proporsi baik di segi bentuk, dan motif desain y ang terdapat pada setiap karya kerajinan berbahan serat daun pandan, Prinsip keseimbangan dari beberapa karya kerajinan berbahan serat daun pandan ini terlihat baik dari kes eimbangan antara bentuk dari elemen utama dengan elemen pendukung lainnya saling mendukung, dan warnayang seimbang dengan motif desain yang ditampilkan. Prinsip irama dari beberapa karya kerajinan berbahan serat daun pandan terlihat baik, karena terdapat elemen yang disusun secara berulang-ulang dengan keberkalaan jarak dan ukuran yang sama sehingga terlihat harmonis. Prinsip dominasi pada beberapa karya kerajinan berbahan serat daun pandan terlihat cukup baik, dilihat dari kontras warna dan motif yang menonjol pada beberapa karya kerajinan ini.

\section{Saran}

Berdas arkan kesimpulan di atas, maka sebagai tindak lanjut penelitian ini dis arankan hal-hal s ebagai berikut: 1). Pengrajin/ pemilik usaha harus lebih berani dalam menciptakan motif dan bentuk desain baru pada karya kerajinan berbahan serat daun pandan ini. Penciptaan desain baru dengan bentuk yang berbeda mengikuti perkembangan zaman, tidak tergantung pada permintaan konsumen saja. Sehingga dapat lebih meningkatkan kreativitas agar motif/corak dan bentuk desain yang diterapkan pada produk lebih variatif, sehingga meningkatkan minat pengunjung dalam membeli produk tersebut, 2). Pen grajin s ebaiknya lebih mengkombinasikan antara karya kerajinan serat daun 


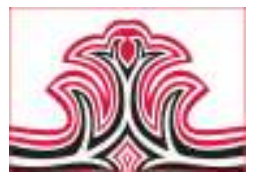

pandan dengan kain perca. Kain perca yang digunakan seperti kain batik, dan ulos. Dan lebih mengkombinasikan antar warna. Hal ini dapat bertujuan agar karya tersebut lebih menarik dan dapat menambah ciri khas suatu daerah dari kain perca yang digunakan tersebut, 3). Perlu adanya kombinasi wama yang variatif, sehingga produk lebih menarik dan tidak terlihat sederhana, 4). Pengrajin/ pemilik usaha sebaiknya memberi kemasan yang baik, agar karya ters ebut tidak mudah rusak dan tidak mudah kotor serta terlihat lebih menarik, dan 5). Penulis mengharapkan industri lebih memperkaya desain-desain kerajinan bahan serat alam khususnya serat daun pandan agar tidak monoton, dan menciptakan dan menambah variasi bentuk baru yang lebih variatif, kreatif, inovatif, dan berkualitas didasari oleh prinsip-prinsip kerajinan. Sehingga menambah minat konsumen untuk membeli produk kerajinan tersebut dan untuk memperluas jangkauan penjualan, disarankan industri untuk membuat website, blog, atau media sosial khusus untuk produk kerajinan yang ada pada industri tersebut.

\section{DAFTAR RUJUKAN}

Alwi, Hasan. (2001). Kamus Besar Bahasa Indonesia. Jakarta: Balai Pustaka.

Annisa, A. (2020). "Produk Pada Karya Kerajinan Daun Pandan". Hasil Wawancara Pribadi: 03 Mei 2020. Industri Chantika Handicraft.

Garha, Oho. (1990). Pokok-Pokok Pengajaran Kerajinan Tangan dan Kesenian. Jakarta: Departemen Pendidikan dan Kebudayaan.

Noerati. (2013). Teknologi Tekstil (Bahan Ajar Pendidikan dan Latihan Profesi Guru). Bandung: Sekolah Tinggi Teknologi Tekstil.

Raharjo. (2011). Seni Kriya dan Kerajinan. Yogyakarta: ISI Yogyakarta.

Stewart, Mary. (2011). Launching the Imagination a Comprehensive Guide to Basic Design. New York: McGraw-Hill.

Sugiyono. (2017). Metode Penelitian Kuantitatif, Kualitatifdan $R \& D$. Bandung: PT Alfabet.

Sunaryo, Aryo. (2002). Nirmana I. Semarang: Universitas Negeri Semarang.

Tanjung, M. H. (2020). "Hasil Karya Kerajinan Daun

Pandan Di Chantika Handicraft". Hasil Dokumentasi Pribadi: 20 Agustus 2020. Industri Chantika Handicraft.

Tjitrosoepomo. (2007). Taksonomi Tumbuhan (Spermatohyta). Yogyakarta: Gadjah Mada University Press.

Widjaja. (1989). Jenis-Jenis Pandan Samak (terjemahan). Jawa Timur: Universitas Jember.
Gorga : Jurnal Seni Rupa

Volume 09 Nomor 02 Juli-Desember 2020

p-ISSN: 2301-5942 | e-ISSN: 2580-2380

Zulkifli. dan Triyanto, R. (2018). Nirmana Dwimatra Elemen, Prinsip, dan Aspek Teknis Seni Rupa dan Desain. Medan: FBS Unimed Press. 